\title{
STUDIES ON RAPID COOLING CONTRACTURE OF FROG TOE MUSCLE IMMERSED IN HYPERTONIC AND HYPOTONIC SOLUTIONS
}

\author{
Toshio SAKaI and Toshitada YoshioKa \\ Department of Physiology, The Jikei University School of Medicine, Tokyo
}

\begin{abstract}
Summary The tension development of rapid cooling contracture (RCC) of toe muscle of Rana nigromaculata treated with $1.0 \mathrm{~mm}$ caffeine in various hypertonic or hypotonic solutions was measured by mechanoelectric transducer. The tension output of RCC decreased in hypertonic $\mathrm{NaCl}$ solution in which the concentration of $\mathrm{NaCl}$ was increased and in hypertonic solution prepared by addition of $\mathrm{KCl}$ to the normal Ringer solution. The RCC tension output was not altered in isotonic solution in which $\mathrm{NaCl}$ was isotonically substituted for $\mathrm{KCl}$ in normal Ringer solution, but it decreased in test solution in which $\mathrm{KCl}$ was hypertonically increased. However, the RCC tension output was not altered in a solution in which urea was hypertonically added to the normal Ringer solution.

The RCC tension output increased in hypotonic solution prepared by reducing the concentration of $\mathrm{NaCl}$ in normal Ringer solution; its value was maintained at an osmotic strength of $200-210 \mathrm{~m} \mathrm{Osm} / \mathrm{kg} \mathrm{H}_{2} \mathrm{O}$ and was reduced at $160 \mathrm{~m} \mathrm{O} \mathrm{sm/} \mathrm{kg} \mathrm{H} \mathrm{H}_{2} \mathrm{O}$.

In conclusion, the tension development of rapid cooling contracture in hypertonic and hypotonic solutions was similar to the data on crayfish muscle (APRIL et al., 1968), in which the ionic strength of the intracellular space is a major determinant of the mechanical response to a given activation of $\mathrm{Ca}$ mechanical coupling.
\end{abstract}

Since the report by OVERTON (1902) it has been recognized that twitch tension development of skeletal muscle is enhanced in hypotonic solutions with a certain limit of osmotic strength and inhibited in hypertonic solution while ordinary action potential is generated (HodGKIN and Horowicz, 1957). SANDOW (1965) has expressed these phenomena in terms of "dissociation of electromechanical coupling." It has been argued, however, that these phenomena might be due mainly to mechanical alteration of intracellular contractile elements rather

Received for publication November 28, 1972

酒井敏夫，吉岡利忠 
than to an electromechanical relationship, i.e., changes of myoplasmic viscosity and intracellular ionic strength with water transference of muscular cells under differing osmotic strength also influence contractile elements (HowARTH, 1958; Podolsky and Sugi, 1967; Hill, 1968).

In other words, intracellular dehydration caused by immersion in hypertonic solution narrows interfilamental space to produce a close package between Aand I-filaments, thus increasing development of filamentary resting tension (FRT) (DYDÝNSKA and WiLKIE, 1968; HiLl, 1968).

In crayfish muscle $\mathrm{Ca}$ activation was inhibited in hypertonic solution and enhanced in hypotonic solution (APRIL et al., 1968). However, CAPUTO (1966) reported that the caffeine contracture in frog muscle was enhanced in hypertonic solution.

This paper deals with the behavior of rapid cooling contracture (RCC) (FUJII and SAKAI, 1969; SAKAI et al., 1971) of frog toe muscle that was treated with a subcontracture concentration of caffeine and soaked in hypertonic or hypotonic solution.

These studies aim at comparison of RCC probably caused by activation of transiently increased $\mathrm{Ca}^{++}$ions in myoplasm with the above-mentioned experimental data on Ca activation of APRIL et al. (1968). A part of this paper was also presented at the seminar of the U.S.-Japan Cooperative Program in Tokyo (1971).

\section{MATERIALS AND METHODS}

Toe muscles (extensor longus digiti IV) of the Japanese frog Rana nigromaculata were used. After measurement of the resting length of the toe muscle in situ and dissection of the muscle specimen, they were immersed in normal Ringer solution for 30-60 min and then fixed to the recording apparatus and twitch tension and tetanus (Po) were recorded at room temperature. The composition of the Ringer solution was as follows: $116.8 \mathrm{mM} \mathrm{NaCl}, 2.5 \mathrm{mM} \mathrm{KCl}, 1.8 \mathrm{~mm} \mathrm{CaCl}$, $2.0 \mathrm{~mm}$ Tris- $\mathrm{HCl}(\mathrm{pH} \mathrm{7.0)} ; 6 \mathrm{mg} \% d$-tubocurarine was also added to the test solution.

Hypertonic or hypotonic test solutions were prepared by increasing or decreasing the concentration of $\mathrm{NaCl}$ in normal Ringer solution, and $\mathrm{KCl}$ hypertonic or urea hypertonic solution was made by increasing $\mathrm{KCl}$ or adding urea to normal Ringer solution. Before the experiment the osmotic strength of the test solution was measured by a freezing point osmometer of Advanced Instrument Inc., Ltd.

The average osmotic strength of the normal Ringer solution was $230 \mathrm{~m}$ Osm/ $\mathrm{kg} \mathrm{H}_{2} \mathrm{O}$. The glycerol hypertonic solution used in the present experiment was $400 \mathrm{~mm}$ glycerol Ringer solution with about 2.7 times the osmotic strength of normal Ringer solution (the same used by HoweLl and JENDEN, 1967).

T-tubule disrupted muscle was prepared by immersion of the muscle in hy- 
pertonic glycerol Ringer solution for $1 \mathrm{hr}$ and then replacement in normal Ringer solution. During immersion of the muscle in glycerol hypertonic solution the T-tubule disruption was confirmed by observation of twitch tension development or tetanus. Rapid cooling was carried out by the procedure devised by SAKAI (1965): After treatment at room temperature with a subcontracture concentration of caffeine or thymol for 5-10 min, the muscle preparation in a 50-ml glass cylinder of normal Ringer solution at room temperature, was cooled rapidly by replacing the another cylinder with a previously cooled solution. Muscle tension was recorded on an oscillograph (Nihon-Kohden Co., Ltd.).

The experiments in the present paper were performed between October 1969 and Feburary 1970 and between July and September 1971.

\section{RESULTS}

\section{The tension development of RCC in hypertonic solution}

Figure 1 indicates the experimental results of $\mathrm{RCC}$ in various hypertonic solutions of $\mathrm{NaCl}$. Twitch tension and tetanus (Po) in normal Ringer solution at room temperature were recorded and then caffeine at $1 \mathrm{~mm}$ final concentration was added to the test solution. To confirm potentiation of twitch caused by caffeine, 20 min later two successive RCCs in normal Ringer solution with $1 \mathrm{~mm}$ caffeine were observed.

In the present experiment maximal tension development of RCC was used as the standard value for calculation of all tension values, and usually it took about 20-30 sec of cooling time to reach the peak of tension. Immediately after maximal tension was observed, rewarming was carried out.

After RCCs were elicited two times at an interval of $20 \mathrm{~min}$ in normal Ringer solution, the muscular preparation was soaked in hypertonic solution. The hypertonicity of the test solution was raised stepwise to $440 \mathrm{~m} \mathrm{Osm} / \mathrm{kg} \mathrm{H}_{2} \mathrm{O}$, and RCCs in the hypertonic solutions were recorded at $20 \mathrm{~min}$ intervals.

As shown in Fig. 1, RCC tension development in hypertonic solutions gradually decreased with rising hypertonicity, as did twitch tension development. In Ringer solution containing $1 \mathrm{~mm}$ caffeine, RCC tension development depends upon the thermal difference of the extracellular solution and varies by season even under exactly the same thermal conditions. In the present experiment, summer frogs were used, and the maximum tension of caffeine-RCC in normal Ringer solution was $77 \pm 10 \%(\mathrm{~N}=21)$ against tetanus $(\mathrm{Po})$.

Figure 2 shows the relationship between relative tension of RCC in various hypertonic solutions and concentration of $\mathrm{NaCl}$ in the test solution. As shown in this figure, even if osmotic strength of the test solution was linearly raised, relative tension development of $\mathrm{RCC}$ dropped reciprocally. This result was similar to the data of APRIL et al. (1968), who investigated the relationship between tension output of crayfish and extracellular osmolarity of test solution. The 


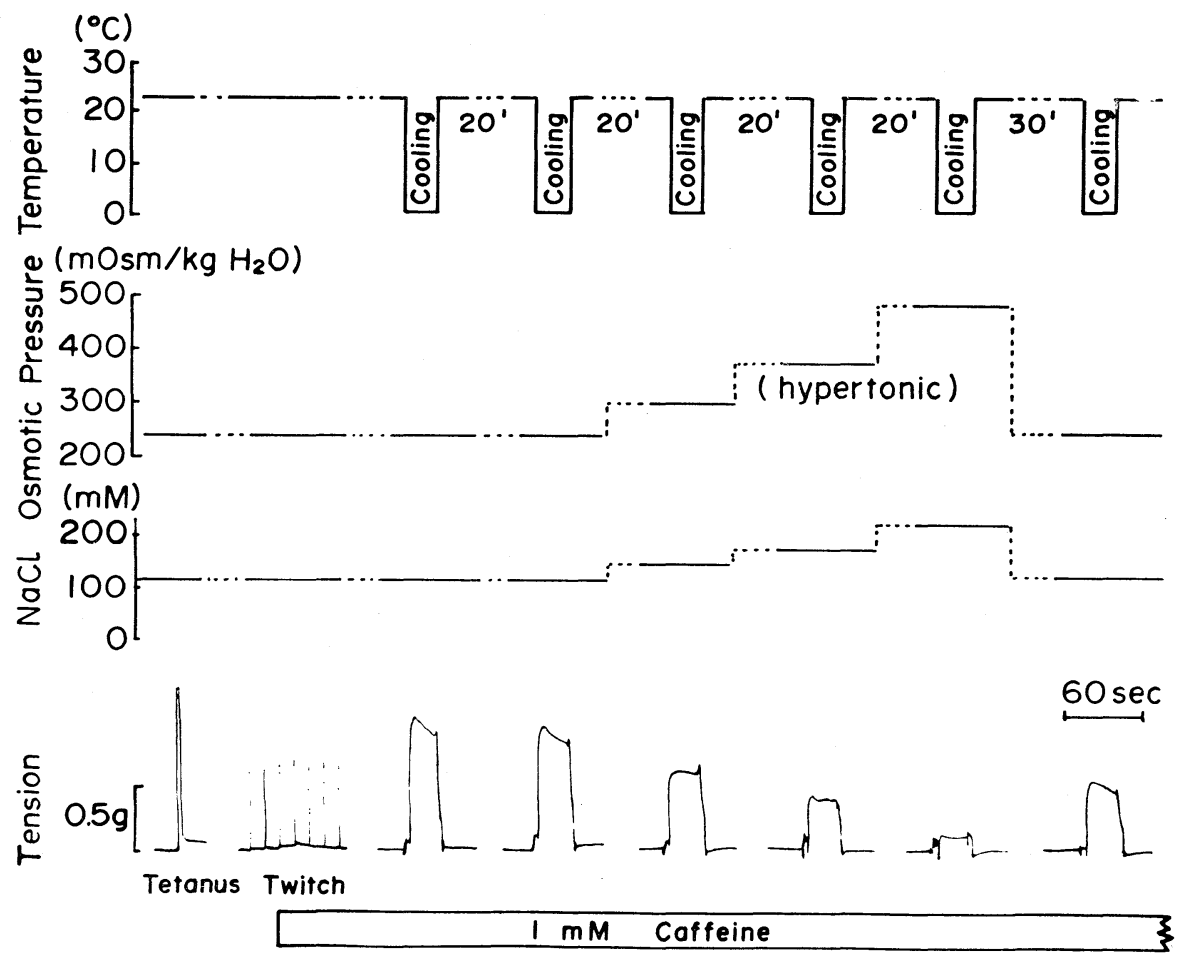

Fig. 1. The inhibitory effect of hypertonic solution on rapid cooling contracture (RCC). At first tetanus tension and twitch were recorded, and then twitch potentiation of $1 \mathrm{~mm}$ caffeine was observed. Twenty minutes after addition of caffeine successive RCCs were recorded at intervals of $20 \mathrm{~min}$ with rapidly lowering temperature from 23 to $0^{\circ} \mathrm{C}$. $\mathrm{RCC}$ in various hypertonic solutions prepared by addition of $\mathrm{NaCl}$ to the normal Ringer solution were recorded at 20-min intervals. Upper row: signal of rapid cooling. Middle row: osmotic strength of the solution and concentration of $\mathrm{NaCl}$ added to the normal Ringer solution. Lower row: tetanus tension (Po), twitch, and RCCs.

tension development of RCC almost vanished in hypertonic Ringer solution of 2.5 times normal osmolarity but on returning to normal Ringer solution it appeared again.

Figure 3 shows the RCC in hypertonic solution in which $\mathrm{KCl}$ was substituted for $\mathrm{NaCl}$, which has been previously discussed with respect to the RCC of depolarized skeletal muscle (SAKAI, 1965). In this experiment, taking into consideration unusual intracellular metabolism and potassium contracture of striated muscle in hypertonic solution containing more than a certain concentration of $\mathrm{KCl}$ (SASLOW, 1937; HowARTh, 1958; MiYAZAKi et al., 1962; NovotnỲ et al., 1962; NovotnỲ and Vyskoc̀IL 1966), RCCs were performed at intervals of $30 \mathrm{~min}$.

No remarkable inhibition of RCCs in $\mathrm{KCl}$ hypertonic solution was observed, 


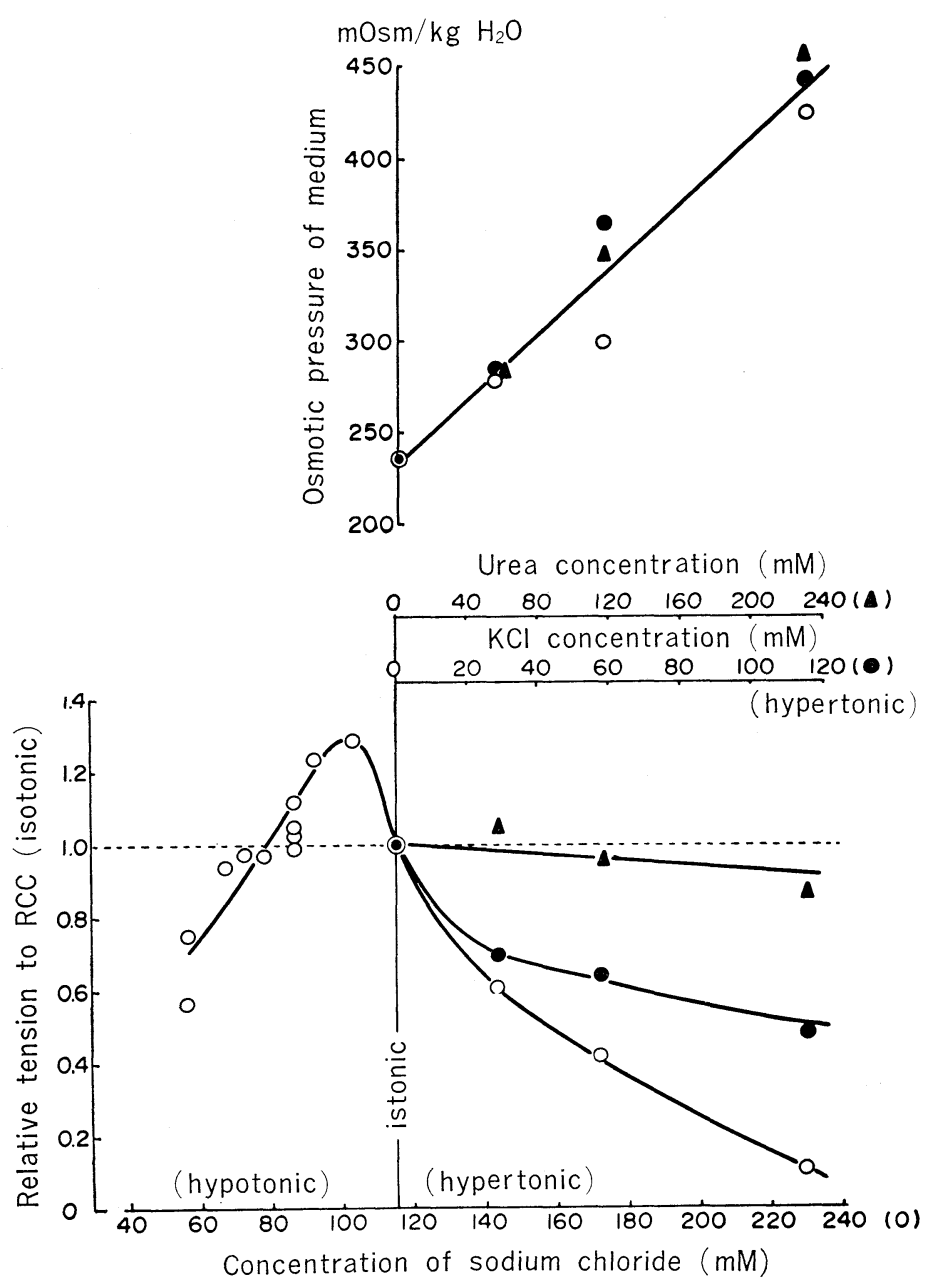

Fig. 2. Relative tension of RCC produced in various hypertonic solutions. The relative tension of RCC in various hypertonic solutions is expressed as relative value against the maximal tension of RCC in normal Ringer solution. $\mathrm{NaCl}$ hypertonic solution was prepared by addition of $\mathrm{NaCl}$ to normal Ringer solution, and also $\mathrm{KCl}$ and urea hypertonic solution were prepared by addition of $\mathrm{KCl}$ and urea as described in the figure. Points of relative tension of $\mathrm{RCCs}$ in $\mathrm{NaCl}$ and $\mathrm{KCl}$ hypertonic solution were obtained from the results shown in Figs. 1 and 2. The value of osmotic strength corresponds to relative tension of RCC observed in various kinds of hypertonic solutions, such as urea hypertonic solution.

but $\mathrm{RCC}$ in $\mathrm{NaCl}$ hypertonic solution was strongly inhibited, as shown in Fig. 2. The relative tension of RCCs obtained in a hypertonic solution of $\mathrm{KCl}$-added Ringer solution is indicated in Fig. 2, which shows that RCC was reciprocally inhibited, even if osmotic strength in the test solution was linearly raised. 

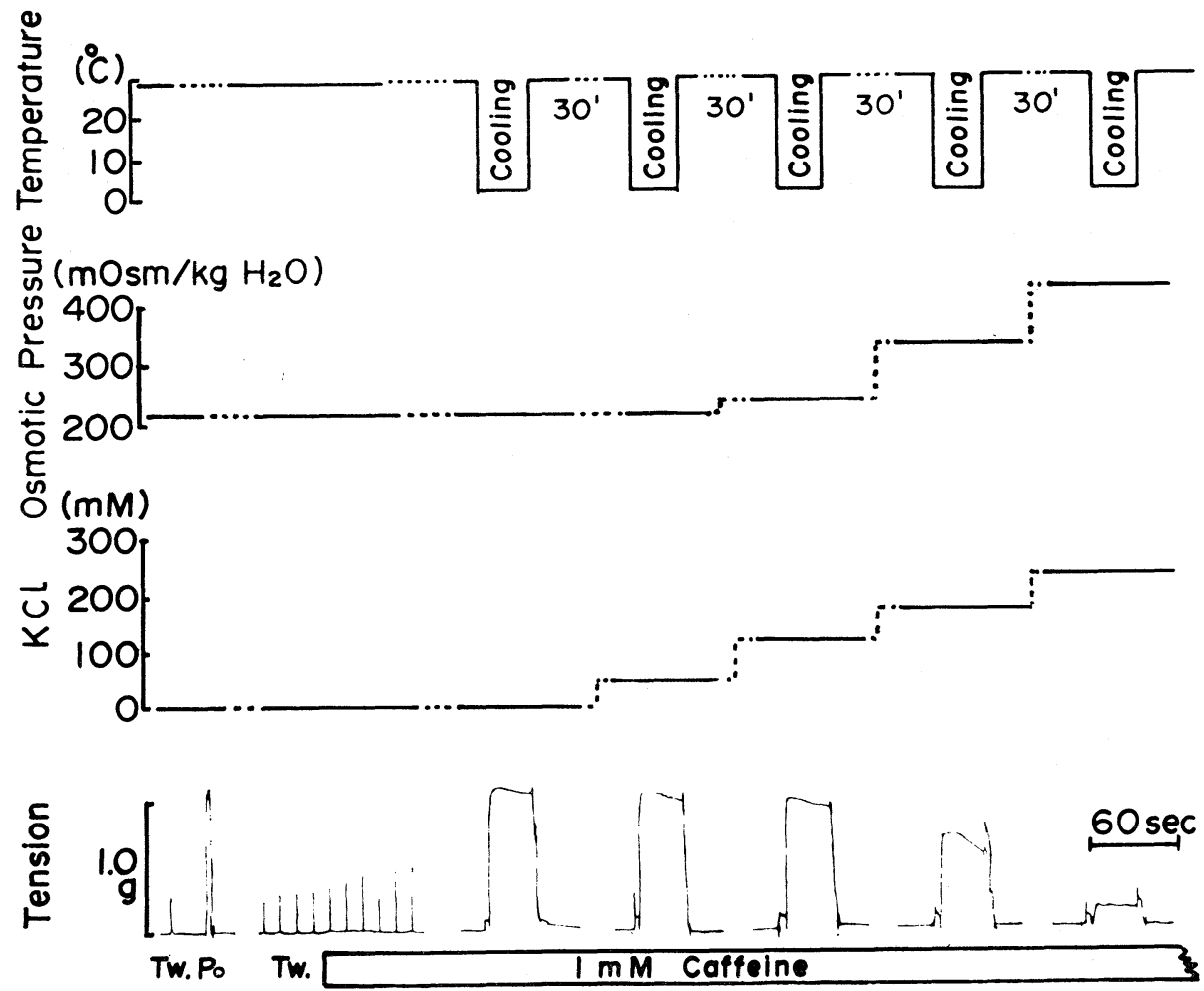

Fig. 3. RCC observed in $\mathrm{KCl}$ hypertonic solution. $\mathrm{KCl}$ hypertonic solution was prepared by addition of $\mathrm{KCl}$ to normal Ringer solution. RCCs were observed at 30-min intervals. Upper row: signal of rapid cooling. Middle row: osmotic strength and concentration of $\mathrm{KCl}$ added to the normal Ringer solution. Lower row: maximal tension of twitch and tetanus and RCC. In this experiment RCC was recorded by rapidly lowering temperature from 27 to $0^{\circ} \mathrm{C}$.

In an isotonic solution in which $\mathrm{KCl}$ was substituted for $\mathrm{NaCl}, \mathrm{RCC}$ could be produced as in normal Ringer solution, but in a raised concentration of $\mathrm{KCl}$, $\mathrm{RCC}$ was partially inhibited. In $450 \mathrm{~m} \mathrm{Osm} / \mathrm{kg} \mathrm{H}_{2} \mathrm{O}$ solution it vanished completely, but on returning the muscle to normal Ringer, RCC was again produced, transiently increased muscle weight returning to the normal value.

In addition, in hypertonic solution made by addition of urea as a nonelectrolyte agent, tension development of RCC was examined. As shown in Fig. 2, in urea hypertonic solution RCC was not inhibited. In this experiment the muscular preparation was immersed in urea hypertonic solution for $30 \mathrm{~min}$ to avoid the transient effect of osmotic strength on RCC (APRIL et al., 1968).

The experiments discussed so far were all performed on intact muscle fibers. However, the RCC of T-tubule disrupted muscle was also investigated using 
$1 \mathrm{~mm}$ caffeine or $50 \mu \mathrm{M}$ thymol, and the results were similar to the results reported by SAKAI et al. (1971).

\section{The tension development of $R C C$ in hypotonic solution}

Tetanus, twitch tension and then $1 \mathrm{~mm}$ caffeine $\mathrm{RCC}$ in normal Ringer solution and hypotonic solution, prepared by decreasing $\mathrm{NaCl}$ concentration in normal Ringer solution, were recorded. When the muscle preparation was soaked in hypotonic solution, it was slightly swollen, unlike the specimens in hypertonic solution, and RCC was enhanced. This enhancement of RCC showed the
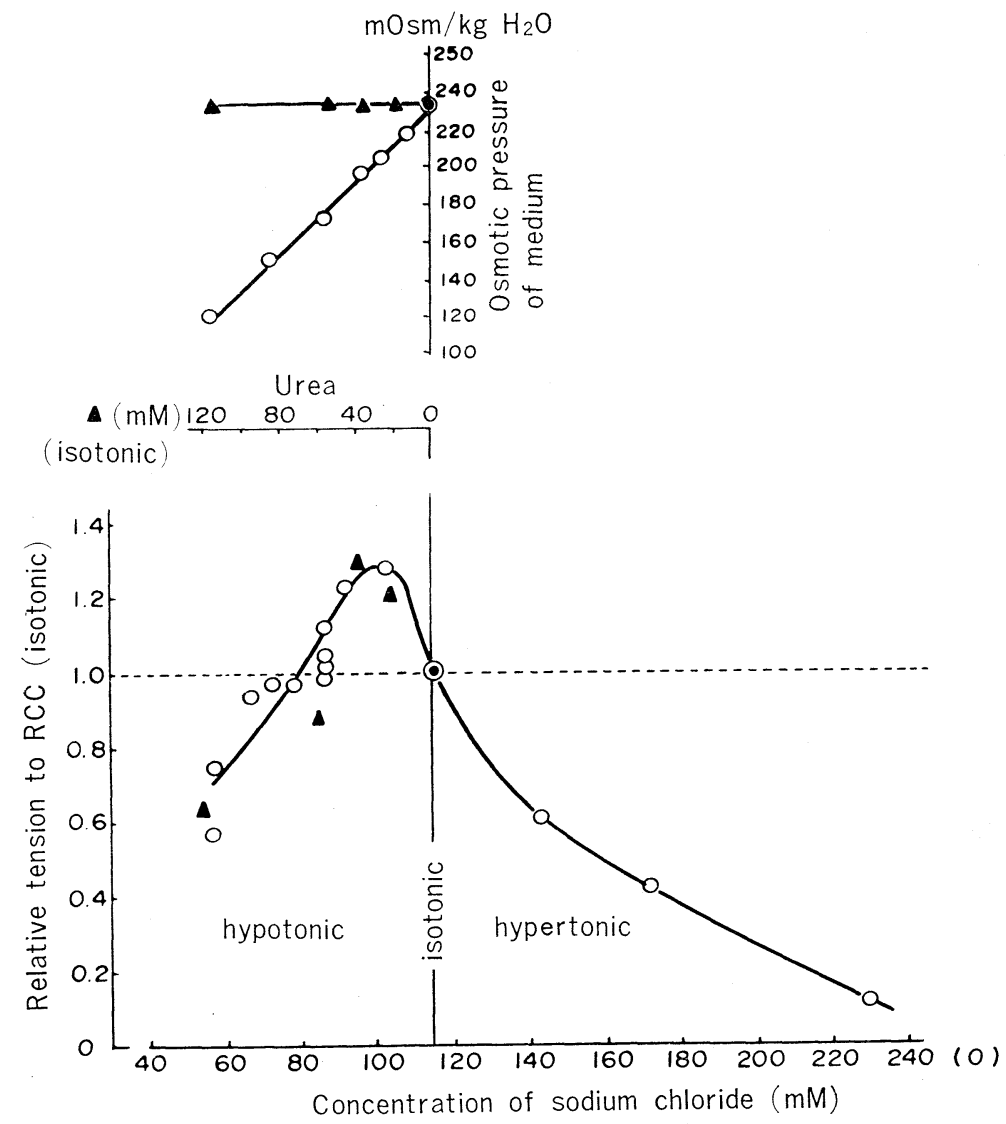

Fig. 4. The relative tension of RCC in hypotonic solution. Hypotonic solution was prepared by reducing $\mathrm{NaCl}$ concentration in normal Ringer solution, and the osmotic strength of the test solution is shown in the upper graph. The relative tension of RCC in hypotonic solution was enhanced at $200-220 \mathrm{~m} \mathrm{Osm} / \mathrm{kg} \mathrm{H}_{2} \mathrm{O}$, and in hypotonic solution less than $200 \mathrm{~m} \mathrm{Osm} / \mathrm{kg} \mathrm{H}_{2} \mathrm{O}$ showed a decreasing trend. When urea was added to the various hypotonic solutions as shown in the figure, the relative tension of RCC in the hypotonic solution was not affected. 
maximum value in $200-210 \mathrm{~m} \mathrm{Osm} / \mathrm{kg} \mathrm{H}_{2} \mathrm{O}$ of test solution, and below that osmotic strength RCC tension development decayed gradually (Fig. 4).

In a hypotonic solution of $160 \mathrm{~m} \mathrm{Osm} / \mathrm{kg} \mathrm{H}_{2} \mathrm{O}$ the $\mathrm{RCC}$ tension output fell more than that in normal Ringer solution. Figures 2 and 4 show these results; in Fig. 4, the relationships between relative tension of RCC, osmotic strength of the test solution, and concentration of $\mathrm{NaCl}$ in the test solution are presented.

The phenomenon of RCC enhancement in hypotonic solution resembled the experimental results of $\mathrm{Ca}^{++}$activation induced by microinjection of calcium ions (APRIL et al., 1968), but the ratio of the enhancement of tension development was small, which might be due to the osmotic effect, as discussed below, i.e., swelling of the muscle cell induced by low osmotic strength might disturb mechanochemical coupling in spite of full activation of the whole muscle cell. Even when urea as a nonelectrolyte agent was added to each hypotonic solution as shown in Fig. 4, the relative tension of RCC was not influenced.
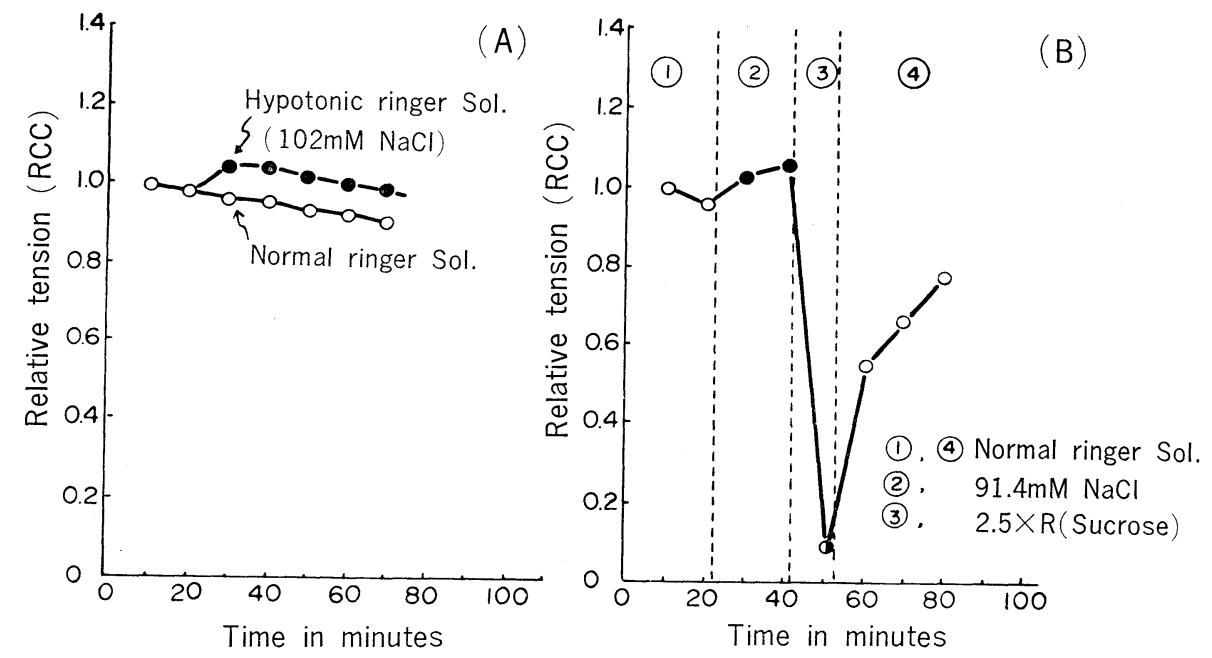

Fig. 5. The effect of hypertonic and hypotonic solutions on RCC. The relative tension of RCCs was calculated from the first peak tension of RCC. (A) $\bigcirc-0$ : $1 \mathrm{~mm}$ caffeine rapid cooling contracture in normal Ringer solution. -0 : $1 \mathrm{~mm}$ caffeine rapid cooling contracture in $102 \mathrm{~mm} \mathrm{NaCl}$ hypotonic Ringer solution. (B) $1 \mathrm{~mm}$ caffeine $\mathrm{RCC}$ in 91.4 mM NaCl hypotonic Ringer was enhanced and inhibited in 2.5 times Ringer solution. Hypertonic Ringer solution was prepared by adding sucrose to normal Ringer solution.

Considering that in a test solution of slightly reduced osmotic strength RCC is known to be enhanced, the following two experiments were performed. First, in normal Ringer and $102 \mathrm{~mm} \mathrm{NaCl}$ hypotonic solution containing $1 \mathrm{~mm}$ caffeine, rapid coolings were carried out continuously at intervals of $10 \mathrm{~min}$, the results of 
which are shown in Fig. 5A. Each value in this figure was obtained from the average of 8 cases. Then, in $91.4 \mathrm{~mm} \mathrm{NaCl}$ hypotonic Ringer, 2.5 times sucrose hypertonic and again normal Ringer solution, rapid coolings were carried out in the presence of $1 \mathrm{~mm}$ caffeine (Fig. 5B). In any hypotonic solution RCCs were enhanced more than in normal Ringer solution.

\section{DISCUSSION}

It has been recognized by many investigators that $\mathrm{Ca}$ microinjection of single muscle fibers can cause Ca-activated contracture (HEILBRUNN and WiERCINSKI, 1947; Niedergerke, 1955; Caldwell and Walter, 1963; April et al., 1968). Recently many investigators (Podolsky, 1962; EBASHI and ENDO, 1968; ENDO et al., 1970; PoDOlsky and TeICHHOLz, 1970) reconfirmed the above phenomena by direct addition of $\mathrm{Ca}$ ions to skinned muscle fibers (NATORI, 1954).

On the other hand, it is well known that the bound $\mathrm{Ca}$ of sarcoplasmic reticulum is released by caffeine (BIANCHI, 1962; HERZ and WEBER, 1965) and produces muscular contracture (Axelsson and ThesLefF, 1958; MAtsumura, 1959; Frank, 1962; LÜtTGAU and Oetliker, 1968; Gebert, 1968). A certain concentration of caffeine above subcontracture concentration at room temperature produces muscular contracture, which is caused by accumulation of released $\mathrm{Ca}$ ions in myoplasm above the threshold concentration for contracture (PORTZEHL et al., 1964).

In muscle fibers treated with a subcontracture concentration of caffeine, reversible contractures are produced by rapid cooling and rewarming (CONWAY and SAKAI, 1960; LÜTtGAU and OetLIKeR, 1968); these have been called rapid cooling contractures (RCC) (FUJII and SAKAI, 1969; SAKAI et al., 1971).

The mechanism of this RCC might be understood as follows:

1) In the presence of caffeine the bound $\mathrm{Ca}$ of sarcoplasmic reticulum is easily released, and the number of released $\mathrm{Ca}$ ions increases in myoplasm.

2) Due to rapid lowering of temperature the $\mathrm{Ca}$ accumulation ability of sarcoplasmic reticulum is reduced and released $\mathrm{Ca}^{++}$gets close to the threshold concentration necessary for muscular contracture.

The total released $\mathrm{Ca}^{++}$increases transiently and produces reversible muscular contracture. According to OGAWA (1970) release of Ca from the fragmented sarcoplasmic reticulum by caffeine was enhanced at low temperature in comparison with that at room temperature.

The RCC, therefore, might also be explained as one of the patterns of $\mathrm{Ca}$ activation (SAKAI, 1965, 1967; FuJI and SAKAI, 1969). On the other hand, the RCC can be observed even in the T-tubule disrupted muscle fibers, as reported previously (SAKAI et al., 1971). There was no difference of tension output of RCC between T-tubule disrupted and non-disrupted muscle fibers, i.e., SR, especially lateral cisternae and longitudinal tubules, might be considered to be a major portion of $\mathrm{Ca}$ uptake and release in the RCC. 
The concept of the RCC mechanism mentioned above agrees with the experimental data of WineGRAD $(1965,1968,1970)$, in which the terminal cisteral of muscle cells might play a main role in Ca release in muscular contraction.

Troponin of myofilaments has an affinity for Ca ions (EBASHI et al., 1967; Podolsky and Teichrolz, 1970). It is still not known if this combining ability of $\mathrm{Ca}$ and troponin is influenced by lowering temperature, but the fact of RCC occurrence implies that it is not disturbed by cold, and sarcoplasmic reticulum will be rather influenced by low temperature. As mentioned above, the mechanism of $\mathrm{RCC}$ has been considered to exist in Ca mechano-coupling, and it is essentially similar to $\mathrm{Ca}^{++}$activation induced by microinjection of $\mathrm{Ca}^{++}$ions, the concentration of which is more than the threshold for contracture.

With respect to the hypertonic solution, however, the problem of whether Ca pumping action especially Ca releasing action is influenced or not still remains. Of interest here is ISAACSON's report (1969) that in hypertonic solution containing radioactive $\mathrm{Ca} \mathrm{Ca}$ efflux in the presence of caffeine was not inhibited in spite of the disappearance of contracture.

The effect of osmolarity on sarcoplasmic reticulum is another problem that should not be ignored. It seems, however, that the contractile element, rather than sarcoplasmic reticulum, is strongly influenced by extracellular osmolarity.

The tension development of RCC in hypertonic solution is similar to the inhibitory trend of twitch in hypertonic solution (HodGKIN and Horowicz, 1957) and muscular contraction evoked by $\mathrm{Ca}^{++}$injection into a muscle cell (APRIL et al., 1968). In muscle fibers soaked in hypertonic solution prepared with $\mathrm{KCl}$ which can be transferred through membranes (Boyle and Conway, 1941), the intracellular ionic strength of potassium is enhanced (HARRIS, 1961). In this muscle preparation, the RCC was partially inhibited (see Fig. 3). Those phenomena are not explained by electromechanical decoupling alone (SANDOw, 1965); rather they suggest that the viscosity of contractile elements would be raised by cellular shrinkage (HowARTH, 1958), and also narrowing of interfilamental space would be produced by changes in ionic strength (BRANDT et al., 1967; AprIL et al., 1968).

The major determinant of the above inhibition of RCC could be Ca mechanical coupling (SANDOW, 1970). This concept is also supported by the present data (Fig. 2) that tension development of RCC was not inhibited in hypertonic solution prepared with such nonelectrolyte agents as urea. When the muscle preparation was soaked in urea hypertonic solution, transient dehydration occurred, and then intracellular ionic strength was reduced with transference of the nonelectrolyte agent into muscle cell (APRIL et al., 1968).

The RCC of skeletal muscle soaked in $200-210 \mathrm{~m} \mathrm{Osm} / \mathrm{kg} \mathrm{H}_{2} \mathrm{O}$ hypotonic solution showed the maximal tension, and so did local contractions evoked by $\mathrm{Ca}^{++}$injection into a muscle in hypotonic solution of similar osmotic strength. Therefore, it seems that within a certain range of osmotic strength the RCC ten- 
sion output was raised, and in extraordinarily low or high osmotic strength, RCC tension output was inhibited.

According to HARRIS (1961), in hypotonic solution water is transferred into a cell, interfilamental space gets wider, and contractile elements themselves are also destructive. However, the reason why RCC tension development is enhanced or inhibited in extraordinarily hyper- or hypotonic solution is still unknown, although those phenomena are constantly observed.

Recently it was reported that ATPase activity of myosin B treated with trypsin would depend upon $\mathrm{KCl}$ concentration in the medium (MARUYAMA et al., 1964), which may help elucidate our findings that varying ionic strength the physicochemical properties of troponin can be altered (EBASHI, 1963; EBASHI and EBASHI, 1964).

This work was supported by a grand from the Education Ministry of Japan and the RCC Research Fund.

\section{REFERENCES}

April, E., Brandt, P. W., Reuben, J. P. and Grundfest, H. (1968) Muscle contraction: the effect of ionic strength. Nature, 220: 182-184.

Axelsson, J. and TheslefF, S. (1958) Activation of contractile mechanism in striated muscle. Acta Physiol. Scand., 44: 55-66.

BIANCHI, C. P. (1962) Kinetics of radiocaffeine uptake and release in frog sartorius. J. Pharmacol., 138: 41-47.

Boyle, J. and Conway, E. J. (1941) Potassium accumulation in muscle and associated changes. J. Physiol., 100: 1-63.

Brandt, P. W., Lopez, E., Reuben, J. P. and Grundfest, H. (1967) The relationship between myofilament packing density and sarcomere length in frog striated muscle. J. Cell Biol., 33: $255-263$.

Caldwell, P. C. and Walter, G. (1963) Studies on the microinjection of various substances into crab muscle fibres. J. Physiol., 169: 353-372.

CAPUTO, C. (1966) Caffeine- and potassium-induced contractures of frog striated muscle fibres in hypertonic solution. J. Gen. Physiol., 50: 129-139.

Conway, D. and Sakai, T. (1960) Caffeine contracture. Proc. Nat. Acad. Sci. (Wash.), 46: 897-903.

DYDÝNSKA, M. and WILKIE, D. R. (1963) The osmotic properties of striated muscle fibres in hypertonic solution. J. Physiol., 169: 312-329.

EвASHI, S. (1963) Third component participating in the superprecipitation of "natural actomyosin". Nature, 200: 1010.

EBASHI, S. and EBASHI, F. (1964) A new protein component participating in the superprecipitation of myosin B. J. Biochem. (Tokyo), 55: 604-613.

Ebashi, S., Ebashi, F. and Kodama, A. (1967) Troponin as the $\mathrm{Ca}^{++}$-receptive protein in the contractile system. J. Biochem. (Tokyo), 62: 137-138.

Ebashi, S. and Endo, M. (1968) Calcium ion and muscle contraction. Progr. Biophys. Mol. Biol. 18: 125-183.

Endo, M., Tanaka, M. and Ogawa, T. (1970) Calcium induced release of calcium from the sarcoplasmic reticulum of skinned skeletal muscle fibres. Nature, 228: 34-36. 
FrANK, G. B. (1962) Utilization of bound calcium in the action of caffeine and certain multivalent cations on skeletal muscle. J. Physiol., 163: 254-268.

FuJI, K. and SAKaI, T. (1969) Electron microscopic studies on "Rapid Cooling Contraction". Jikeikai Med. J., 16: 75-84.

GeBERT, G. (1968) Caffeine contracture of frog skeletal muscle and of single muscle fibres. Am. J. Physiol., 215: 296-298.

Harris, E. J. (1961) The site of swelling in muscle. J. Biophys. Biochem. Cytol., 9: 502-504.

HeILBRunN, L. V. and Wiercinski, F. J. (1947) The action of various cations on muscle protoplasm. J. Cell Comp. Physiol., 29: 15-32.

Herz, R. and Weber, A. (1965) Caffeine inhibition of Ca uptake by muscle reticulum. Fed. Proc., 24: 208.

HILL, D. K. (1968) Tension due to interaction between the sliding filaments in resting striated muscle. J. Physiol., 199: 638-684.

Hodgkin, A. L. and Horowicz, P. (1957) The differential action of hypertonic solutions on twitch action potential of a muscle fibre. J. Physiol., 136: 17.

Howarth, J. V. (1958) The behaviour of frog muscle in hypertonic solutions. J. Physiol., 114: $167-175$.

Howell, J. N. and Jenden, D. J. (1967) T-tubules of skeletal muscle. Fed. Proc., 26: 553.

IsAACSON, A. (1969) Caffeine-induced contractures and related calcium movements of muscle hypertonic media. Experimentia, 25: 1263-1265.

LÜtTGAU, H. C. and OetLiker, H. (1968) The action of caffeine on the activation of the contractile mechanism in striated muscle fibres. J. Physiol., 194: 51-74.

Matsumura, M. (1959) The mechanism of caffeine contracture. Juntendo Med. J., 5: 265268 (in Japanese).

Maruyama, K., Ishikawa, Y. and Ebashi, S. (1964) Effect of several relaxing agents on the ATPase activity of trypsin-treated myosin B. J. Biochem. (Tokyo), 55: 581-583.

MiYAZAKI, E., YABU, H. and TAKahashi, M. (1962) Increasing effect of caffeine on the oxygen consumption of skeletal muscle. Jap. J. Physiol., 12: 113-123.

NATORI, R. (1954) The property and contraction process of isolated myofibrils. Jikeikai Med. J., 1: 119-126.

NIEDERGERKe, R. (1955) Local muscular shortening by intracellularly applied calcium. $J$. Physiol., 128: 12-13.

Novotný, I., Vyskoc̀il, F., VykLICKỲ, L. and BerÀnek, R. (1962) Potassium and caffeine induced increase of oxygen consumption in frog muscle and its inhibition by drugs. Physiol. Bohemoslov., 11: 277-294.

NovotnÝ, I. and Vyskoc̀IL, F. (1966) Possible role of Ca ions in the resting metabolism of frog sartorius muscle during potassium depolarization. J. Cell Physiol., 67: 159-168.

OGAWA, Y. (1970) Some properties of frog fragmented sarcoplasmic reticulum with particular reference to its response to caffeine. J. Biochem. (Tokyo), 67: 667-683.

Overton, E. (1902) Beiträge zur allgemeine Muskel- und Nerven-Physiologie. Pfüger. Arch. Ges. Physiol., 92: 115-280.

Podolsky, R. J. (1962) The structural changes in isolated myofibrils during calcium-activated contractions. J. Gen. Physiol., 45: 613-614A.

Podolsky, R. J. and SUGI, H. (1967) The influence of external hypertonic solutions on the contractile mechanism of skeletal muscle fibres. J. Gen. Physiol., 50: 2496-2497.

Podolsky, R. J. and TeichHolz, L. E. (1970) The relation between calcium and contraction kinetics in skinned muscle fibres. J. Physiol., 211: 19-35.

Portzehl, H., CAldwell, P. C. and RüEGG, J. C. (1964) The dependence of contraction and relaxation of muscle fibers from the crab Maria Squinado on the internal concentration of free calcium ions. Biochem. Biophys. Acta, 79: 581-591. 
SAKAI, T. (1965) The effect of temperature and caffeine on activation of contractile mechanism in the striated muscle fibres. Jikeikai Med. J., 12: 88-102.

SAKAI, T. (1967) Mechanism of contraction-relaxation cycle. 17th Gen. Assembly Japan Med. Congr., Nagoya, 203-206 (in Japanese).

Sakai, T., GeffNer, E. S. and SAndow, A. (1971) Caffeine contracture in muscle with disrupted transverse tubules., Am. J. Physiol., 220: 712-717.

SAKAI, T. (1971) Contractile mechanism of rapid cooling contracture. Excitation-contraction coupling in muscle. U.S.-Japan Cooperative Science Program., Nov. 1st-3rd, Tokyo.

SANDow, A. (1965) Excitation-contraction coupling in skeletal muscle. Pharmacol. Rev., 17: 265-320.

Sandow, A. (1970) Skeletal muscle. Ann. Rev. of Physiol., 32: 87-138.

SASLOW, G. (1937) Oxygen consumption and respiratory quotient of caffeinized frog muscle. J. Cell Comp. Physiol., 10: 385-394.

WINEGRAD, S. (1965) Autoradiographic studies of intracellular calcium in frog skeletal muscle. J. Gen. Physiol., 48: 445-479.

WINEGRAD, S. (1968) Intracellular calcium movements of frog skeletal muscle during recovery from tetanus. J. Gen. Physiol., 51: 65-83.

WinEGRAD, S. (1970) The intracellular site of calcium activation of contraction in frog skeletal muscle. J. Gen. Physiol., 55: 77-88. 